\title{
National budget policy as a factor of economic growth dynamics
}

\author{
Prateep Wajeetongratana ${ }^{1 *}$ \\ ${ }^{1}$ FMS, Suan Sunandha Rajabhat University, 1 U-Thong Nok rd, 10200, Dusit, Bangkok, Thailand
}

\begin{abstract}
In the paper based on the authors' approach to the definition of strategies for fair and effective social compensation, as well as proposed methodology for calculating the indicators of social compensation strategies feasibility, the conclusions regarding macroeconomic conditions of selecting a state participation program in the process of economic achievements converting into social conditions were done, recommendations on modernization the social compensation policy in the dynamics of integrating markets were also offered.
\end{abstract}

\section{Introduction}

The success of modern state economic progress is connected not only with its achievement of a certain level of material prosperity, forming of comfortable conditions for doing business necessarily reflected in the country's attractiveness to foreign capital, but with efficiency of country's economic success converting in the quality of own citizens life (the level of personal incomes, the state of social infrastructure, the completeness and targeting of social programs, the development of human potential and so on).

Thus, our research aim is to analyze the macroeconomic statistics and the rate of economic progress in various countries of the world so that to determine the correlation between the stability of national economic growth on the one hand and the depth of country's integration into the world markets on the other; to develop a set of conceptual recommendations based on the macroeconomic indicators analysis and aimed at modernizing the national strategy of social compensation, adequate to the globalization dynamics of the 21 st century [1].

In accordance with the research aim we set forward the following research tasks:

- using the author's original methodology we will determine the stability index for economic development of various contemporary countries worldwide. The study period covers the most recent 15 years for which the full data is available. Then, the countries will be classified according to their values of this index, and these values will be compared and correlated with other important macroeconomic features of the same countries (for example, GDP per capita, natural resource potential, consumer market capacity);

- a correlation will be determined between the indicators of economic growth stability and external trade activity of the selected contemporary countries, the latter will be again classified, now depending on the dynamics of their trade balance;

* Corresponding author: prateep.wa@ssru.ac.th 
- to outline the most contemporary factors of national economic growth stabilization, all being correlated with the dynamics of external trade of the selected countries. To offer author's recommendations concerning the possible strategic guidelines as per stabilization of national economic development rates.

- propose authorial indices reflecting the role of the state in social compensation policy implementing (fair policy and effective policy) that are possible for calculation using available secondary information, macroeconomic indicators of the countries of the world;

- analyze these indices changes with dynamics of Ginny coefficient in the countries of the world, assess the effectiveness of the national social compensation program in countries grouped by the level of per capita income;

- give recommendations on directions and principles of national policy of social compensation modernization which is relevant for the dynamics of the global market situation.

\section{Research hypotheses}

1. Availability of strategic supply of natural resources and also agricultural lands are not the most decisive factors of economic growth stabilization for today's countries;

2. Countries with high indicators of material welfare will demonstrate not high, but still very stable rates of economic development;

3. Dynamic (or intensive, that is, at least $4 \%$ per annum) rate of economic growth during the whole period in question (15 years) simple cannot be stable all the time;

4. There is a direct correlation between stability of national export growth and stability of country's economic growth overall;

5. The most vital factors of economic growth stabilization are not the impressive indicators of national export or import but the dynamics of their change in time.

\section{Literature Review}

Due to current multimodality of the world economy, functioning of various economic systems differ by their fundamental features (the very construction of the national socioeconomic system, the type and practices of reproduction, the role of the state, the functions of business etc.). Obviously, these national socioeconomic systems also have differences in terms of their geographical and climatic features, natural resource potential etc $[2,3,4]$. For this and other reasons, cross-country studies are always of significant scientific interest, since only such studies can provide the necessary conclusions and recommendations concerning the specificity of national economic growth strategies' development and implementation.

For example, Robert J. Barro [5,6] analyzed the data on 100 contemporary (at that time) economies during the period of their economic establishment and development (1960 till 1990) and came to the conclusion that growth is negatively related to the initial level of real per capita GDP and also that political freedom has only a rather weak effect on growth, and also that once a moderate level of democratic development is reached - its further expansion would only reduce the growth.

Shungo Sakaki [7], in the same research context, came to the conclusion that income distribution is independent from long-term economic growth, and that management of the income distribution ratio enables the promotion of the growth driven by the replacement of the existing technology with new knowledge stock. In the countries where income is not that highly concentrated and larger share of it operates within market economy, the consumer demand-driven economic policy is effective. On the other hand, in a society 
where income is highly concentrated, the investment demand promotes growth by increasing concentration at the growth phase, while in the sluggish phase, a temporary equalization of distribution enables the creation of a new growth course by inducing a technological change brought about by consumer demand $[8,9,10]$.

Ju, J. et al [11]; Samosir, O.B. \& Rajagukguk, W. [12], Fojtíková, L. \& Staníčková, M. [13] studied the external preconditions for economic growth stabilization in contemporary countries (in particular, active involvement in external economic operations). And they revealed that liberalization of markets and of external economic activities worldwide has its negative impact on stable growth of national economic systems.

Dependence of today's economies' growth on export diversification was also evaluated by Lindert, P. [14] and Badri Narayan Rath, Vaseem Akram [15] on the sample of South Asian countries. They came to the conclusion that export diversification causes economic growth in the long run, whereas no causality found in the short run, thus, they suggested that export diversification is crucial for avoiding the volatility in export growth and for enchantment of productivity growth, at least for the economies of the South Asian region.

Hadi Salehi Esfahani [16] showed that the correlation between export/import and economic growth has been mainly due to the contribution of exports to the reduction of import shortages which tend to restrict output growth. In this sense, export promotion is particularly important for those countries which cannot obtain sufficient foreign aid or capital.

The present study using the achievements of cross-state assessments of the economic role of budgetary social expenditures in the countries of the world, as well as theoretical conclusions on the correlation between the dynamics of public expenditure and economic growth, attempts to evaluate an effectiveness of social compensation in countries of the world.

\section{Methodology of the study}

In our research and analysis we have been mostly operating the statistical information of the World Bank (from their official site - worldbank.org). From this large massive of data, we have extracted the needed information on the 150 countries of the world, the study period being from 2000 till 2017.

In order to determine the indicators of economic growth stability we have used the statistical method of mean-square deviation calculation in the indicators of economic growth dynamics as well as the indicators of national export and import growth for all the analyzed countries during these 15 years in question. The obtained results are presented in Table 1.

As it is shown in Table 1, during the period of 2000-2017 the most stable economic growth has been demonstrated by the developing countries of Asia and Africa, and also by some developed - but noteworthy, distanced from the global economic processes and world turmoil overall Australia and Norway. Both these countries, apart from having powerful technological and industrial platforms for such an impressive economic growth, also have sufficient strategic reserves of natural raw materials. Among other developed countries rather stable economic growth has been observed in France, USA, Canada, Austria and Denmark.

At the same time, economic growth stability of Japan turns out to be on the same level with Tunisia (a country still feeling the consequences of the severe political crisis), while the dynamic economic growth of India was rather unstable, thus, the indicator of this country turns out to be on the same level with Italian economy (the latter demonstrated mostly negative dynamics in the several recent years). The absolute leader in terms of economic growth stability during the first 15 years of the 21 century became Norway, while 
its closest geographical neighbor, Sweden, has found itself on the same level with Mexico and Brazil (the indicators of Finland are even lower). Most of fluctuations in economic growth among the well-to-do countries have been demonstrated by Ireland and Iceland. Countries, exporting raw materials (first of all - hydrocarbons) and thus having low diversification of their trade and economy overall, such as Azerbaijan, Nigeria, Russia and the United Arab Emirates - all find themselves in the last third of the list (100-150 ranks). Therefore, we can state that our hypothesis \#1 is confirmed.

Table 1. Indicators of economic growth stability and of external economic activeness of the countries, 2000 to 2017 (calculated by the author on the basis of the World Bank statistics).

\begin{tabular}{|c|c|c|c|c|c|c|c|c|c|}
\hline \multicolumn{2}{|l|}{ Stability of economic growth } & \multicolumn{3}{|c|}{$\begin{array}{c}\text { Stability of national export } \\
\text { development }\end{array}$} & \multicolumn{3}{c|}{$\begin{array}{c}\text { Stability of national import } \\
\text { development }\end{array}$} \\
\hline$\#$ & Country & $\begin{array}{c}\text { Indica } \\
\text { tor }\end{array}$ & $\#$ & Country & Indicator & $\#$ & Country & $\begin{array}{c}\text { Indicat } \\
\text { or }\end{array}$ \\
\hline \multicolumn{8}{|c|}{ Leading countries } \\
\hline 1 & Vietnam & 2.83 & 1 & Malaysia & 14.92 & 1 & Ethiopia & 9,4 \\
\hline 2 & Indonesia & 2.93 & 2 & Senegal & 15.14 & 2 & Russia & 13.23 \\
\hline 3 & Australia & 2.98 & 3 & Thailand & 16.22 & 3 & Norway & 14.4 \\
\hline 4 & Bangladesh & 3.35 & 4 & C. Rica & 16.34 & 4 & Canada & 14.41 \\
\hline 5 & Lao & 3.78 & 5 & Sweden & 16.92 & 5 & Lesotho & 15.89 \\
\hline 6 & Cameroon & 4.48 & 6 & Poland & 17.29 & 6 & Australia & 16.44 \\
\hline 7 & Tanzania & 4.67 & 7 & France & 18.11 & 7 & Malaysia & 16.53 \\
\hline 8 & Guatemala & 4.99 & 8 & Mexico & 18.59 & 8 & Swaziland & 17.53 \\
\hline 9 & Norway & 5.21 & 9 & Cyprus & 19,11 & 9 & Mexico & 18.26 \\
\hline 10 & Bolivia & 5.47 & 10 & Croatia & 19,21 & 10 & UK & 18.46 \\
\hline \multicolumn{8}{|c|}{ A separate group of large countries } \\
\hline 17 & USA & 6.38 & 11 & UK & 19,81 & 22 & Germany & 23.75 \\
\hline 26 & S. Africa & 6.9 & 15 & Germany & 21.58 & 42 & Italy & 27.95 \\
\hline 32 & UK & 7.49 & 20 & Russia & 23.33 & 50 & Turkey & 29,82 \\
\hline 35 & China & 7.61 & 40 & USA & 28.12 & 62 & Brazil & 33.58 \\
\hline 47 & India & 8.44 & 70 & S. Africa & 36.03 & 73 & Thailand & 37.38 \\
\hline 48 & Italy & 8.45 & 78 & India & 39,23 & 86 & S. Africa & 39,71 \\
\hline 53 & Germany & 9,02 & 86 & China & 41.87 & 96 & China & 42.05 \\
\hline 63 & Thailand & 9,78 & 93 & Turkey & 43.24 & 101 & India & 44.29 \\
\hline \multicolumn{8}{|c|}{ Outsiders } \\
\hline 146 & CAR & 39,55 & 146 & Congo & 135.97 & 146 & Nigeria & 135 \\
\hline 147 & Zimbabwe & 39,83 & 147 & S. Leone & 141.03 & 147 & Congo & 148.8 \\
\hline 148 & S. Leone & 40.13 & 148 & Chad & 142.9 & 148 & Chad & 150.4 \\
\hline 149 & Liberia & 43.76 & 149 & Liberia & 144.81 & 149 & Serbia & 159,4 \\
\hline 150 & S. Sudan & 51.36 & 150 & Argentina & 148.1 & 150 & Liberia & 511.5 \\
\hline
\end{tabular}

As Table 2 clearly shows, among the countries with the maximum average rate of economic growth during the $2000-2017$ period, there is no leader as such in terms of economic dynamics' stability. Moreover, correlation between macroeconomic indicators is 0.06 , which basically means no correlation as such between them. Analysis of the obtained data confirms that high indicators of economic growth during the period in question (high here means at least $4 \%$ per annum) in the majority of countries is demonstrating it was accompanied by great deal of economic instability (however, with the exception of 9 countries, namely, Bangladesh, Bolivia, China, India, Indonesia, Malaysia, Tanzania, Thailand, Vietnam). This confirms our hypothesis \#2. 
Table 2. Stability of economic growth vs average rate of economic growth by countries of the world, 2000-2017 (compiled by the author on the basis of the World Bank statistics).

\begin{tabular}{|c|c|c|c|c|c|}
\hline$\#$ & Country & $\begin{array}{c}\text { Average rate of } \\
\text { economic growth, } \\
2000-2017\end{array}$ & $\#$ & Country & $\begin{array}{c}\text { Stability of } \\
\text { economic } \\
\text { growth }\end{array}$ \\
\hline \multicolumn{7}{|c|}{ Leading countries } \\
\hline 1 & Azerbaijan & 10.94 & 1 & Vietnam & 2.83 \\
\hline 2 & China & 9,59 & 2 & Indonesia & 2.93 \\
\hline 3 & Ethiopia & 9,03 & 3 & Australia & 2.98 \\
\hline 4 & Turkmenistan & 8.51 & 4 & Bangladesh & 3.35 \\
\hline 5 & Chad & 8.31 & 5 & Laos & 3.78 \\
\hline 6 & Rwanda & 8.03 & 6 & Cameroon & 4.48 \\
\hline 7 & Tajikistan & 7.83 & 7 & Tanzania & 4.67 \\
\hline 8 & Cambodia & 7.82 & 8 & Guatemala & 4.99 \\
\hline 9 & Bhutan & 7.61 & 9 & Norway & 5.21 \\
\hline 10 & Nigeria & 7.54 & 10 & Bolivia & 5.47 \\
\hline \multicolumn{7}{|c|}{ Outsiders } & & 31.72 \\
\hline 141 & Brunei Darussalam & 1.02 & 141 & Kosovo & 33.68 \\
\hline 142 & South Sudan & 0.95 & 142 & Chad & 34.69 \\
\hline 143 & Yemen & 0.94 & 143 & Yemen & 37.84 \\
\hline 144 & Japan & 0.89 & 144 & Azerbaijan & 39,55 \\
\hline 145 & Jamaica & 0.69 & 145 & CAR & 39,83 \\
\hline 146 & Portugal & 0.42 & 146 & Zimbabwe & 40.13 \\
\hline 147 & Italy & 0.24 & 147 & Sierra Leone & 43.76 \\
\hline 148 & Greece & 0.16 & 148 & Liberia & 51.36 \\
\hline 149 & CAR & -0.01 & 149 & South Sudan & 64.73 \\
\hline 150 & Zimbabwe & -0.01 & 150 & Iraq & \\
\hline
\end{tabular}

Table 3. Correlation between the indicators of economic growth, national export, national import and payment balance (in \% of national GDP, 2000-2017) (calculated by the authors).

\begin{tabular}{|c|c|c|c|}
\hline \multirow{2}{*}{$\begin{array}{c}\text { Indicators in } \\
\text { correlation }\end{array}$} & $\begin{array}{c}|c| \\
\text { National export } \\
\text { volume }\end{array}$ & National import volume & $\begin{array}{c}\text { Payment balance of } \\
\text { the country }\end{array}$ \\
\cline { 2 - 4 } & 0.12 & 0.19 & -0.09 \\
\hline $\begin{array}{c}\text { Stability of national } \\
\text { economic growth }\end{array}$ & $\begin{array}{c}\text { Stability of national } \\
\text { export growth }\end{array}$ & $\begin{array}{c}\text { Stability of national } \\
\text { import growth }\end{array}$ & $\begin{array}{c}\text { Stability of payment } \\
\text { balance growth }\end{array}$ \\
\hline $\begin{array}{c}\text { Stability of national } \\
\text { economic growth }\end{array}$ & 0.53 & 0.58 & 0.54 \\
\hline
\end{tabular}

At the second stage of our research we calculate the correlation between the indicators of economic growth stability and the volumes of exports and imports, as well as with the indicators of exports/imports growth stability (in dynamics). At this, we have obtained the following correlations (see Table 4).

As Table 3 clearly shows, there is literary zero correlation between the indicators of economic growth stability and the volumes of national import, export and payment balance (measured as \% of national GDP). However, if we take the indicators of external economic activity of countries in their dynamics (stability of national export/import growth and stability of payment balance) - those demonstrate certain connection with stability of countries' overall economic growth. Therefore, for economic stability maintenance the most important factor is stability of export/import growth but not the actually achieved indicators of export/import. Thus, we can state that our hypothesis \#3 is partially 
confirmed. There is an obvious dependence of economic growth stability from the relative indicators of export and import, but not from their absolute values. This means hypothesis \#4 is fully confirmed.

At the final stage of our research countries of the world have been classified into four groups according to the values of their payment balance (positive or negative) and also taking into account the dynamics of their economic growth (here, dynamic growth means at least $4 \%$ a year, on average, throughout the whole period in question - 2000 to 2017; in the opposite case the growth is considered to be slow). For these groups we got the following correlations (see Tables 4 and 5).

Table 4. Correlation between economic growth, national export, national import and payment balance

(in \% of national GDP during 2000-2017) in the countries with negative and positive payment balance (calculated by the author).

\begin{tabular}{|c|c|c|c|c|c|c|}
\hline \multirow{2}{*}{$\begin{array}{c}\text { Indicators in } \\
\text { correlation }\end{array}$} & \multicolumn{2}{|c|}{$\begin{array}{c}\text { Stability of national } \\
\text { export growth }\end{array}$} & \multicolumn{2}{|c|}{$\begin{array}{c}\text { Stability of national } \\
\text { import growth }\end{array}$} & \multicolumn{2}{|c|}{$\begin{array}{c}\text { Stability of payment } \\
\text { balance growth }\end{array}$} \\
\cline { 2 - 7 } & $\begin{array}{c}\text { Countries } \\
\text { with } \\
\text { positive } \\
\text { balance of } \\
\text { payments }\end{array}$ & $\begin{array}{c}\text { Countries } \\
\text { with } \\
\text { negative } \\
\text { balance of } \\
\text { payments }\end{array}$ & $\begin{array}{c}\text { Countries } \\
\text { with } \\
\text { positive } \\
\text { balance of } \\
\text { payments }\end{array}$ & $\begin{array}{c}\text { Countries } \\
\text { with } \\
\text { negative } \\
\text { balance of } \\
\text { payments }\end{array}$ & $\begin{array}{c}\text { Countries } \\
\text { with } \\
\text { positive } \\
\text { balance of } \\
\text { payments }\end{array}$ & $\begin{array}{c}\text { Countries } \\
\text { with } \\
\text { negative } \\
\text { balance of } \\
\text { payments }\end{array}$ \\
\hline $\begin{array}{c}\text { Stability of } \\
\text { economic } \\
\text { growth }\end{array}$ & 0.57 & 0.34 & 0.58 & 0.42 & 0.72 & 0.41 \\
\hline
\end{tabular}

Our results from evaluation of correlation between economic growth stability and dynamics of key macroeconomic indicators for the groups of countries, as described above, shows that this correlation is much more significant for the countries with positive trade balance (these are 49 countries from the analyzed) and also for the countries with rather slow but still average economic growth (around 4\%) throughout the whole period of 20002017.

Table 5. Correlation between the indicators of economic growth, national export/import and payment balance (in \% to national GDP, 2000-2017; calculated separately for the countries with dynamics and with slow economic growth).

\begin{tabular}{|c|c|c|c|c|c|c|}
\hline \multirow{2}{*}{$\begin{array}{c}\text { Indicators in } \\
\text { correlation }\end{array}$} & \multicolumn{2}{|c|}{$\begin{array}{c}\text { Stability of national } \\
\text { export growth }\end{array}$} & \multicolumn{2}{|c|}{$\begin{array}{c}\text { Stability of national } \\
\text { import growth }\end{array}$} & \multicolumn{2}{|c|}{$\begin{array}{c}\text { Stability of payment } \\
\text { balance growth }\end{array}$} \\
\cline { 2 - 7 } & $\begin{array}{c}\text { Countries } \\
\text { with } \\
\text { dynamic } \\
\text { economic } \\
\text { growth }\end{array}$ & $\begin{array}{c}\text { Countries } \\
\text { with slow } \\
\text { economic } \\
\text { growth }\end{array}$ & $\begin{array}{c}\text { Countries } \\
\text { with } \\
\text { dynamic } \\
\text { economic } \\
\text { growth }\end{array}$ & $\begin{array}{c}\text { Countries } \\
\text { with slow } \\
\text { economic } \\
\text { growth }\end{array}$ & $\begin{array}{c}\text { Countries } \\
\text { with } \\
\text { dynamic } \\
\text { economic } \\
\text { growth }\end{array}$ & $\begin{array}{c}\text { Countries } \\
\text { with slow } \\
\text { economic } \\
\text { growth }\end{array}$ \\
\hline $\begin{array}{c}\text { Stability of } \\
\text { economic } \\
\text { growth }\end{array}$ & 0.5 & 0.72 & 0.52 & 0.68 & 0.54 & 0.71 \\
\hline
\end{tabular}

\section{Discussion}

Our analysis of correlations between economic growth indicators and dynamics of external trade operations for various countries of the world (2000-2017) proves that growth of both export and import may have quite a stabilizing influence on the economic development of

\footnotetext{
$\dagger$ Trade balance of countries - as of 2017

* We took into account the average indicators of GDP growth by countries, 2000 to 2015
} 
the countries, however, only provided the trade balance is positive. A separate analysis of this correlation by the decile groups of countries (divided according to the volume of their trade balance) demonstrates that the highest correlation is observed for the top deciles (the countries with the maximum positive trade balance - Ireland, Turkmenistan, Brunei Darussalam, Gabon, Switzerland, Thailand, Netherlands, Maldives, Slovenia, Hungary) and also in the countries where trade balance is close to zero (Cyprus, Bulgaria, Greece, Nigeria, Belarus, Chile, Finland, Japan, Uruguay, Swaziland). At the same time, for the countries with the negative balance of payments external trade operations have very little or none at all influence on economic growth and its stability.

Therefore, we can make a theoretical conclusion that even in the 21 st century maintaining positive trade balance is still the key decisive factor for economic growth and development of countries, regardless the availability of many other options for growth and development - such as instruments of the international financial market, well-developed service sector, transfer of innovations etc. However, there is a big difference from the classical times of traditional mercantilism: nowadays growth of import can lead to economic stability only provided export growth is still higher (even if insignificantly, when the trade balance is still quite close to zero). Negative trade balance, in the majority of cases worldwide, is still among the most destabilizing factors for economic growth.

Rapid economic growth tends to have mostly negative influence on the stability of economic systems. This is quite logical if we take into account the imminent restructuring of the whole economic system in favor of most dynamically developing sectors, temporary financial misbalance (and a significant one), investment "overheating", limiting state capacities in timely and efficient regulation of the economic system which is developing too quickly (and states, traditionally, tend to be always late in their reaction). Under the conditions of rather dynamic economic growth indicators of external trade may change suddenly and dramatically: for example, export of readymade product from the developing sectors may suddenly grow, thus causing also quite sudden growth in imports of the related raw materials and technologies. All these quick changes will cause abrupt fluctuations in trade balance and balance of payments, they may also lead to significant changes in international labor migration, cross-country investment flows etc. Obviously, all these changes - being abrupt and often not quite predictable - will have their negative influence on the stability of economic growth of countries. Finally, too rapid economic growth may lead to overdependence of a country from foreign consumption due to fluctuations of the world prices. In a longer term, this can limit the economic development horizon as such (the most typical scenario will include full degradation of the non-growing sectors because all their resources have been moved to more profitable sectors which sooner or later will have its negative impact on internal consumption). All these trends and manifestations tend to increase destabilization effects manifold, even if annual reduction of GDP rate is not that significant (in such a situation skeptical sentiments or even panic emerge too easily, thus causing capital outflow from a country, lower prices of raw materials, higher prices at consumption markets etc.).

Thus, taking into account the outlined specificity of economic development of the countries during the early years of the 21 st century, we can also formulate a range of vital requirements to the process of strategy development and implementation so that to make national economic growth more stable and long-term, even under all the risks and uncertainties related to unavoidable integration of the world markets.

\section{Conclusions and Recommendations}

Today, dynamic economic growth (again, dynamic here means more than $4 \%$ per annum) would be nearly impossible without intensive external trade and cross-country borrowing of 
production factors. Many countries worldwide do not have enough internal capacities for economic development this quick. This means neither they have the economic strength to guarantee own long-term and stable economic growth on the basis of external trade only (as statistical analysis clearly shows this trade potential survives usefulness during some 8-10 years only). Among all 150 countries we have analyzed here only two (Croatia and Guinea Bissau) had outstripping economic growth (meaning every new year the indicator was always higher than in the previous year) during at least 12 years (out of 15 overall). In 19 more countries (including India, UAE and Pakistan) such outstripping growth was observed for 11 years. And in Germany, Russia and Denmark it was recorded only for 6 consecutive years. The worst indicator in this regard got Southern Sudan -4 years since the year this country got independence. In the absolute majority of the studied countries (72 out of 150) this outstripping growth lasted for 8-9 years, and this rather short term significantly limits governmental efforts when it comes to change of priorities and strategic guidelines in national economic development.

Relatively small volumes of national export or import do not necessarily mean lack of economic growth. For example, to the group of 20 countries with the smallest volumes of national exports belong Pakistan, Haiti and Columbia, and all three economies have also demonstrated rather average dynamics of GDP growth - slightly less than 3\%. Majority of the analyzed countries, including the United States, had the economic growth on the level of $3.8-4.5 \%$ throughout the studied period.

If we analyze the import indicators separately - the situation is more explicit. To the group with minimum import volumes belong very different countries, including Brazil (the average rate of economic growth $-4.2 \%)$, Japan (7\%), USA $(3.8 \%)$, China $(5.1 \%)$, India $(3.7 \%)$, Indonesia $(1.6 \%)$. Therefore, we can state that slow-but-steady economic development by means of internal reserves is possible even in the 21 st century, and the only major problem for the governments striving to develop their countries under sanctions, for example, or under high external competition with neighbors would be finding sufficient internal reserves for this growth. And the key sources for these resources are internal consumption and internal competitive environment. Better internal consumption means internal demand must be efficiently satisfied (and this, in turn, means that internal demand will develop qualitatively further), while more competitive internal environment means that the most competitive enterprises and sectors must be developed in a country.

In the case when a state is actively integrating into the world markets, its strategies of economic growth stabilization must guarantee, in the first place, not necessarily high indicators of export, import and trade balance - but stability of positive dynamics in these indicators, even under global instability and constant fluctuations at the strategic markets of raw materials, food products and electronic services. This is why stabilization of economic growth in a country must be seen as, first of all, reducing its dependence from externalities, for example, through diversification of external economic activities. This diversification should include the following items: monitoring the contributions of all important trade partners making sure none of them is getting too risky large share in export or import; stimulation of competition between foreign agents and at foreign markets; widening the area of export activities etc. At the same time, development of internal markets must rest on maintaining the sectoral balance in national economy (for example, through introduction of mandatory quotas for all large exporters of what they must sell internally; flexible taxation and budget policies, both aimed at regulation of intersectoral flows of investments, labor force, resources etc.; promotion of regional cooperation which would allow, on the one hand, to accumulate the advantages of external trade (foreign distribution, availability of resources and production factors), and on the other - to localize many economic processes so that they can be better regulated, controlled and forecasted by regional authorities. 


\section{References}

1. D. Ushakov. Intern. J. Of Environmental \& Science Education 18, 1113, (2016).

2. R. Amano, T. Wirjanto. Rev. of Econ. Dynamics 1(3), 17. (1998).

3. A. Dreher. Europ. J. of Political Economy 22(1), 83. (2006).

4. A. Dreher, J. Sturm, H. Ursprung. Public Choice 134(3-2), 263. (2008).

5. R. Barro. J. of Political Economy 98(5), 23. (1990).

6. R. Barro. Determinants of Economic Growth: A Cross-Country Empirical Study (MIT Press Books, 1998).

7. S. Sakaki. The Annals of Reg. Sc. 38(2), 199 (2004).

8. T. Kelly. J. of Development Studies 34(1), 11 (1997).

9. G. Scully. Public Choice 108(1), 123 (2001).

10. H. Tanninen. Applied Economics 31(9), 1109 (2010).

11. J. Ju, Y. Wu, L. Zeng. IMF Staff Papers 57(2), 427 (2010).

12. O. Samosir, W. Rajagukguk. EUrASEANs 5(6), 36 (2017).

13. L. Fojtíková, M. Staníčková. EUrASEANs 2(3), 29 (2017).

14. P. Lindert. Explorations in Economic History 33(1), 1 (1996).

15. B. Narayan Rath, V. Akram. J. of Soc. and Econ. Development 19(1), 196 (2017).

16. H. Esfahani. J. of Development Economics 35(1), 93 (1991). 